\title{
A primary neuroendocrine tumor of the left ventricle presenting with diarrhea-an unusual experience and literature review
}

\author{
Chengfang Li', Jiajia Huang ${ }^{1}$, Xiaorong Yang ${ }^{1}$, Jinhua Xia ${ }^{1}$, Gaoqiang $\mathrm{Xu}^{2}$ and Hong Zheng ${ }^{1 *}$
}

\begin{abstract}
Background: Neuroendocrine tumors (NETs) can secrete bioactive amines in the bloodstream, resulting in the carcinoid syndrome characterized by diarrhea and flushing. The frequency of occurrence of primary cardiac neuroendocrine neoplasms is lesser than that of metastases, and hence, metastases must be adequately ruled out before diagnosis. Cardiac tumors, both primary and metastatic, mainly result in heart-related symptoms, such as heart failure and acquired valvular dysfunction. Here, we report a unique case of a primary left ventricular neuroendocrine tumor presenting with diarrhea.

Case presentation: A 51-year-old female complaining of intermittent diarrhea for 2 years was admitted to our hospital. Enhancement of total abdominal computed tomography scan, echocardiography, and magnetic resonance imaging indicated a mass in the left ventricle. The indexes of myocardial enzymes were normal. Histologically, round cells with well-differentiated neuroendocrine morphology were arranged in typical pseudo-glandular, trabecular, ribbon-like, and solid nest patterns. Immunohistochemically, the tumor cells were positive for cytokeratin, chromogranin, synaptophysin, and CD56. However, they were negative for caudal type homeobox 2, S100, paired box gene 8, thyroid transcription factor 1, and CD20, which ruled out the origin of gastrointestinal, pancreatic, lung, and Merkel cell carcinomas. The symptoms of diarrhea disappeared after the operation. The patient was asymptomatic at the 9-month follow-up.

Conclusion: Cardiac neuroendocrine tumors with diarrhea are considerably rare and related clinical research is limited. We presented a case and reviewed related articles to improve the identification, diagnosis, and management of patients with cardiac neuroendocrine tumors. The site of origin of a neuroendocrine tumor is clinically vital, and identification of an occult primary tumor using imaging modalities is necessary. Immunohistochemistry is well-suited to indicate the origin of the tumor. Regular follow-up is necessary for both poorly differentiated and well-differentiated cardiac neuroendocrine tumors. It is suggested to detect some neuroendocrinal markers for patients with unexplained reasons of diarrhea.
\end{abstract}

Keywords: Neuroendocrine tumor, Cardiac, Carcinoid syndrome, Immunohistochemistry

\section{Background}

Cardiac tumors can be either primary or metastatic. Primary tumors of the heart are exceedingly rare, with an incidence rate of 0.0017 to $0.19 \%$ in unselected autopsy series [1]. Tumors that metastasize to the heart are more common than primary tumors, similar to metastatic breast carcinomas, melanomas, lymphomas, leukemia, and sarcomas. Neuroendocrine tumors (NETs) of the heart are extremely rare, and most metastasize

\footnotetext{
* Correspondence: zhenghonghq@hotmail.com

'Department of Pathology, The Affiliated Hospital of Zunyi Medical

University, Zunyi 563000, Guizhou, China

Full list of author information is available at the end of the article
}

from gastrointestinal or pulmonary tumors. Therefore, the presence of metastatic tumors should be ruled out before the diagnosis of primary cardiac NETs. NETs can produce various biologically active substances that are capable of eliciting symptoms of the carcinoid syndrome (CS) [2] such as diarrhea and flushing. CS is the most established of all hormonal syndromes and is caused by release of 5-hydroxytryptamine (serotonin), bradykinins, and many other mediators. NET is also a cause of acquired valvular heart disease, with cardiac involvement described in up to $60 \%$ of patients with CS [3]. A population-based study showed that the frequency of occurrence of CS in patients with NET was $19 \%$. CS is

(c) The Author(s). 2020 Open Access This article is distributed under the terms of the Creative Commons Attribution 4.0 International License (http://creativecommons.org/licenses/by/4.0/), which permits unrestricted use, distribution, and 
significantly associated with tumor grade, stage, and primary tumor site, and leads to shorter survival [4].

To our knowledge, patients with cardiac tumors typically present with few symptoms until the neoplasm is considerably large or has metastasized, at which point they present heart-related symptoms such as heart failure and acquired valvular dysfunction. The clinician's challenge is to detect the tumor before the appearance of cardiac symptoms and to exclude metastatic neuroendocrine tumors from tumors of other origin using immunohistochemistry and other adjuvant examination. Here, we report the case of a patient with primary cardiac NET, which prompted a literature review on this topic.

\section{Case presentation} Clinical history

A 51-year-old female, who had been complaining of intermittent diarrhea for the previous 2 years, was admitted to our hospital with recurrent watery diarrhea along with abdominal pain for 3 days. The patient had received intermittent treatment of anti-inflammatory drugs and symptomatic treatment for 2 years due to recurrent diarrhea. However, the treatment was not effective and she had lost $5 \mathrm{~kg}$ body weight. To determine the specific cause of weight loss and recurrence of diarrhea, the doctor examined the patient thoroughly. No abnormality was evident in gastroscopy and proctoscopy. Enhancement of total abdominal computed tomography (CT) scan suggested a suspected space occupation in the left ventricle. Echocardiography indicated a $45 \mathrm{~mm} \times 28 \mathrm{~mm}$ mass in the left ventricle, and a malignant tumor was suspected (Fig. 1a). Magnetic resonance imaging (MRI) was performed to confirm the diagnosis; the image showed an oval mass measuring $28 \mathrm{~cm} \times 26 \mathrm{~cm} \times 41 \mathrm{~cm}$ in the inferior wall of the left ventricle with unclear boundary and limited movement, and equal $\mathrm{T} 1$ and long T2 signals (Fig. 1b, c, d), and a myxoma was suspected. All the indexes of myocardial enzymes were normal. The urine metabolites were normal with exception of slightly elevated calcium levels $(2.68 \mathrm{mmol} / \mathrm{L}$, normal reference range: $2.20-2.65 \mathrm{mmol} / \mathrm{L}$ ) and slightly elevated phosphorus levels $(1.95 \mathrm{mmol} / \mathrm{L}, \quad 0.81-1.45 \mathrm{mmol} / \mathrm{L})$. The patient was transferred from the Department of Gastroenterology to that of Cardiac Surgery for surgical tumor resection.

\section{Operation}

The mass was relatively isolated. Hence a median sternotomy was performed, cardiopulmonary bypass was initiated, and the heart was arrested with antegrade cardioplegia. The mass, located in the left ventricle measuring $35 \mathrm{~mm} \times 25 \mathrm{~mm}$, adhered to the myocardium of the diaphragmatic surface. Sharp dissection was performed circumferentially around the capsule of the mass, ensuring macroscopically free tumor margins. The heart restarted automatically when the ascending aorta was opened, although the heart rate was slow (60 times/ min); it was then sewn to the pacemaker wire on the heart surface, after which it worked well. After chest closure, the patient was transferred to the cardiovascular intensive care unit for routine care. Her course was uneventful with the exception of reduction in hemoglobin and platelet levels, and slight increase in lactate dehydrogenase level.

\section{Pathology}

Macroscopically, the lesion consisted of a $3 \mathrm{~cm} \times 2 \mathrm{~cm} \times$ $1.5 \mathrm{~cm}$ grayish yellow mass with a complete capsule and medium texture.

Histological analysis showed that the complete capsule of the tumor was visible at low magnification (Fig. 2a). Round tumor cells of well-differentiated neuroendocrine morphology were arranged in typical pseudo-glandular, trabecular, ribbon-like, and sieve-like patterns (Fig. 2b, c). The cells were well-differentiated (Fig. 2d), no tumor necrosis was detected, and the mitotic count was $2 / 10 \mathrm{HPF}$.

\section{Immunohistochemistry}

The tumor cells were positive for cytokeratin (CK), CD56, chromogranin (CGA), neuron-specific enolase (NSE) (Fig. 3b, c, d), and synaptophysin (Syn), and were negative for vimentin and S100. The proliferative index of Ki67 was $2 \%$. Diagnosis of neuroendocrine tumor (G1) was based on the results of immunohistochemistry and morphological analysis. Metastatic tumors were considered first because of the special anatomical location of the tumor. Further investigations with multiple imaging modalities, focusing on the appendix, gastrointestinal tract, pancreas, and lungs, did not reveal any primary tumor. Immunohistochemistry plays an important role in differential diagnosis in the absence of other tumor lesions. Hence, immunohistochemistry was performed with thyroid transcription factor 1 (TTF1) to rule out the possibility of tumor origin in the lung, with paired box gene 8 (PAX8) to rule out origin in the pancreas, with caudal type homeobox 2 (CDX2) to rule out origin in the gastrointestinal tract, and with CD20 to rule out Merkel cell carcinoma. However, the results for these makers were all negative.

The final pathological diagnosis was primary welldifferentiated neuroendocrine tumor (WDNET) of the left ventricle (G1).

\section{Outcome and follow-up}

The course of the patient was uneventful, and the symptoms of abdominal pain and diarrhea disappeared after the operation. She was discharged 10 days after the 

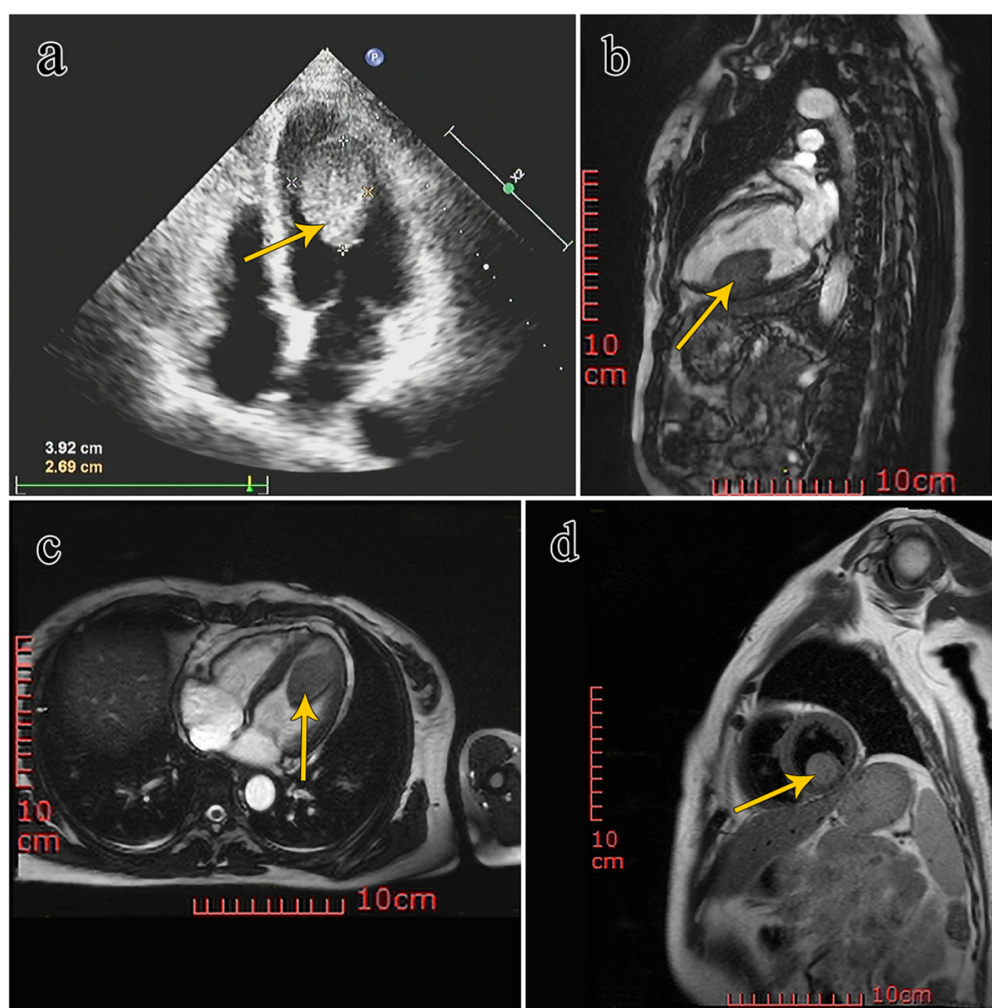

Fig. 1 a Echocardiography showed a homogeneous mass in the left ventricle (the yellow arrow). b, c Magnetic resonance imaging (MRI) showed a longer T2 signal of the left ventricular mass (the yellow arrow). $\mathbf{d}$ MRI demonstrating round mass with clear boundary in left ventricle (the yellow arrow)

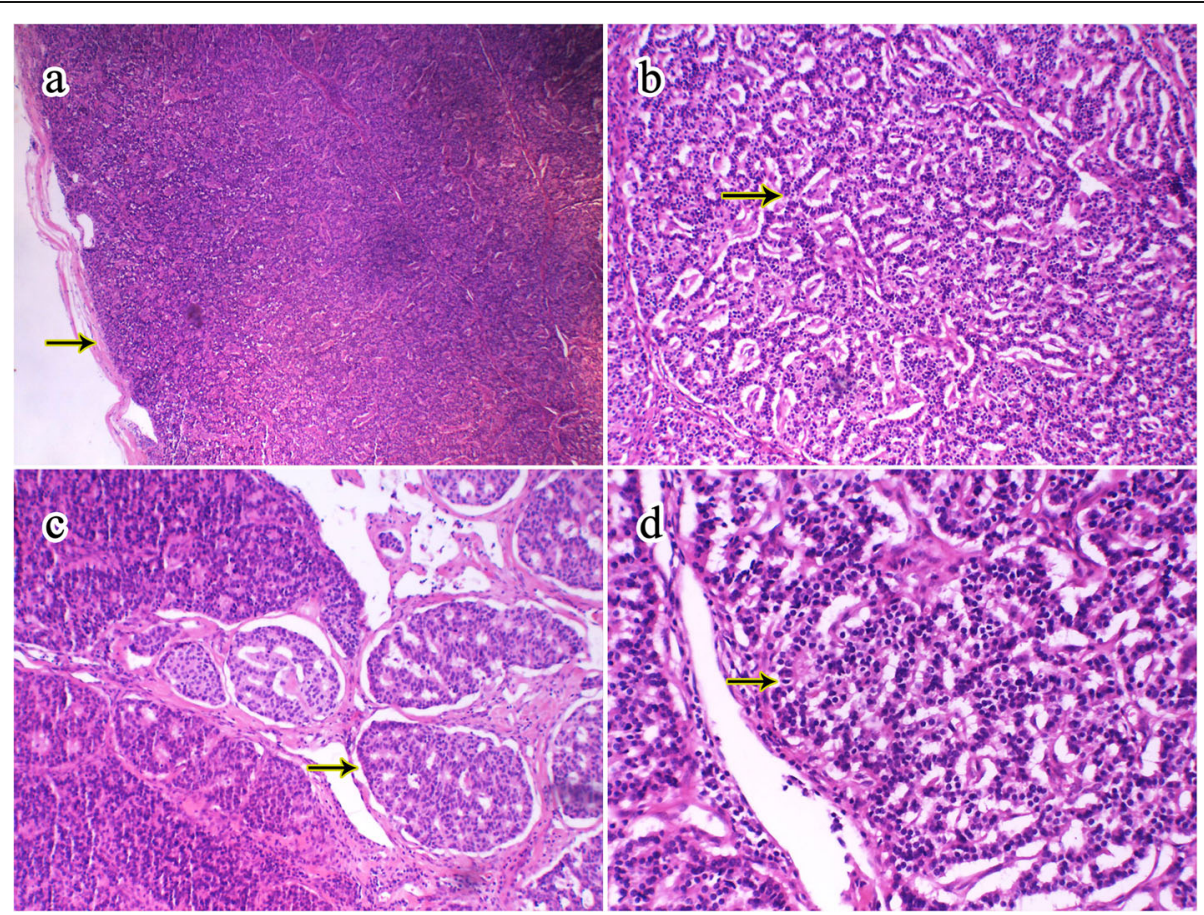

Fig. 2 The image of HE. a showed a complete capsule of the mass (40x, the arrow); b demonstrated tumor cells arranged with pseudo-glandular (the arrow), c presented sieve-like patterns in tumor cells (100x). $\mathbf{d}$ The round cells were well-differentiated (200x) 


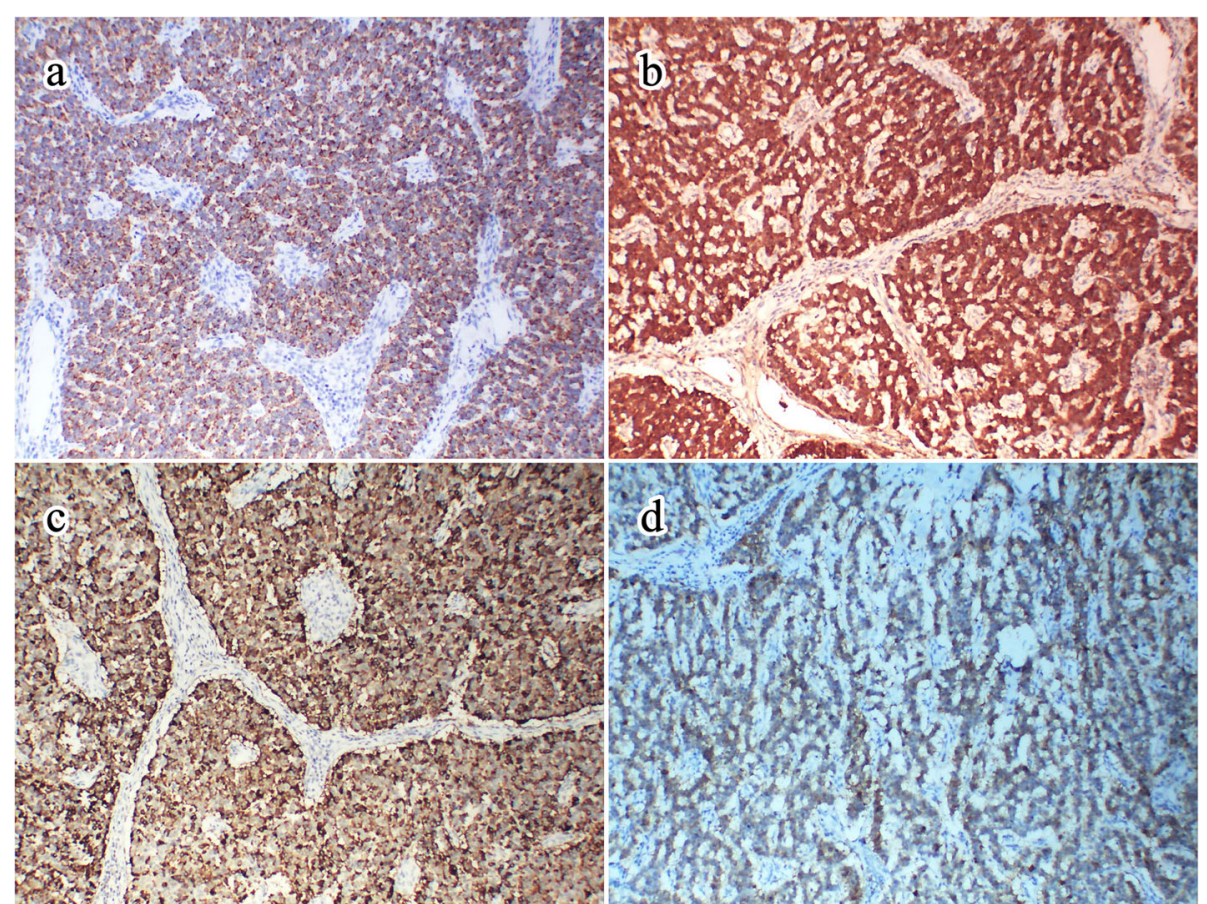

Fig. 3 The image of immunohistochemistry. a represented the tumor cells were dot-like positive for CK (100x). b, c showed diffusely cytoplasmic positive for NSE, CGA respectively in tumor cells (100x). d Tumor cells showed patchy cytoplasmic positive for CD56 (100x)

operation and returned to the hospital for reexamination at 3,6 , and 9 months post-operation. The patient was asymptomatic, with no abnormality in cardiac function and no recurrence of tumor and diarrhea.

\section{Discussion}

Neuroendocrine neoplasms (NENs) are a heterogeneous group of epithelial neoplastic lesions that show features of neural and endocrine differentiation, including the ability to produce amines and/or peptide hormones irrespective of their primary site of origin [5]. Cardiac neuroendocrine tumors are extremely rare and are usually the result of metastatic disease. So far, only five cases of primary cardiac neuroendocrine tumors have been reported (Table 1). To the best of our knowledge, this is the first report of a patient with primary cardiac neuroendocrine tumor presenting watery diarrhea.

NETs release vasoactive peptides and amines, such as serotonin and tachykinins, resulting in CS. The most common symptoms of CS are diarrhea and flushing, and less commonly, bronchospasm and telangiectasia [11]. CS is predominantly encountered in patients with midgut NETs, the most frequently observed primary sites for NET being the small bowel, although it can also occur in patients with NETs of other origin [4]. The presence of watery diarrhea, in association with cutaneous facial flushing (especially when associated with elevated serotonin blood levels), and radiographic evidence of malignancy is almost always diagnostic of CSassociated diarrhea [12]. In the present case, the patient suffered from an unknown cause of watery diarrhea for 2 years, which resulted in high psychological and economic burden. Unexpectedly, the diarrhea disappeared after tumor resection. CS diarrhea is largely a consequence of tumoral secretion of serotonin, which results in reduced absorption of water and electrolytes, leading to diarrhea [13-15]. In our present case, serotonin blood levels were not determined because of the technical limitations of our institution, normal urine metabolites of the patient may be due to his intermittent symptomatic treatment in the local hospital. Although there is not enough laboratory data to prove that the patient had carcinoid syndrome, we highly suspected it to be CS-associated diarrhea.. The other five reported cases of cardiac neuroendocrine tumors were associated with chest pain, syncope and hypotension, heart failure and cyanosis, progressive dyspnea, and hypotension and dyspnea, respectively (Table 1). Most of the patients with cardiac neuroendocrine tumors showed local symptoms of the heart, and none suffered from diarrhea (Table 1). The symptom of diarrhea in the present case misled the clinicians, and hence the condition had not been correctly diagnosed and treated for two years. This was a case of well-differentiated neuroendocrine tumor, which was consistent with previous reports showing that CS 
Table 1 Clinicopathologic features of primary cardiac neuroendocrine neoplasms

\begin{tabular}{|c|c|c|c|c|c|c|c|}
\hline NO./Ref. & Sex/age & Location & Symptoms & Operation/Treatment & $\mathrm{IHC}$ & $\begin{array}{l}\text { Histological } \\
\text { classification }\end{array}$ & Follow-up \\
\hline $1[6]$ & $\mathrm{M} / 50$ & $\begin{array}{l}\text { LV and } \\
\text { RV }\end{array}$ & Chest pain & $\begin{array}{l}\text { Chemotherapy+Heart } \\
\text { transplantation }\end{array}$ & $\begin{array}{l}\mathrm{CK}^{+}, \mathrm{CD} 56^{+}, \mathrm{SYN}^{+}, \\
\mathrm{CGA}^{+}, \mathrm{P} 3^{+}\end{array}$ & G3 & $\begin{array}{l}\text { Multiple metastases } \\
11 \text { month post } \\
\text { operation }\end{array}$ \\
\hline $2[7]$ & $M / 54$ & LA & Syncope and hypotension & Local biopsy+ chemotherapy & $\begin{array}{l}\mathrm{CD}^{+} 9^{+}, \mathrm{CD}^{2} 6^{+}, \mathrm{CD}^{2} 7^{+} \\
\mathrm{NSE}^{+}, \mathrm{SYN}^{+}, \mathrm{CK}^{+} ;{\mathrm{S} 100^{-}}^{-} \\
\mathrm{CGA}^{-}, \mathrm{THF}^{-}\end{array}$ & G3 & $\begin{array}{l}\text { Alive but multiple } \\
\text { metastases } 1 \text { year } \\
\text { later }\end{array}$ \\
\hline $3[8]$ & $F / 68$ & RV & Heart failure and cyanosis & $\begin{array}{l}\text { Surgical tumour } \\
\text { resection+chemotherapy }\end{array}$ & No provide & G2 & $\begin{array}{l}\text { Asymptomatic at a } \\
\text { 9-month follow-up } \\
\text { visit }\end{array}$ \\
\hline $4[9]$ & $\mathrm{M} / 70$ & RA & Progressive dyspnea & $\begin{array}{l}\text { Palliative surgical } \\
\text { tumour resection+radiation } \\
\text { therapy }\end{array}$ & $\begin{array}{l}\mathrm{CK}^{+}, \mathrm{CK}^{-} \mathrm{O}^{+}, \mathrm{SYN}^{+} \\
\text {vimentin } \\
\text { Melan-A } \\
\text { MCK } \\
\text { MCA }\end{array}$ & G3 & $\begin{array}{l}\text { Multiple metastases } \\
\text { and died } 18 \text { months } \\
\text { postoperatively }\end{array}$ \\
\hline $5[10]$ & $F / 68$ & LV & Asymptomatic & Surgical tumour resection & $\mathrm{SYN}^{+}, \mathrm{CGA}^{+}, \mathrm{CAM} 5.2^{+}$ & G1 & $\begin{array}{l}\text { Asymptomatic at } \\
\text { 6-month clinic } \\
\text { follow-up }\end{array}$ \\
\hline $6^{a}$ & $F / 51$ & LV & Diarrhea & Surgical tumour resection & $\begin{array}{l}\mathrm{SYN}^{+}, \mathrm{CGA}^{+}, \mathrm{CD}^{+} 6^{+}, \\
\mathrm{CK}^{+}, \mathrm{NSE}^{+}, \mathrm{Ki}-672 \% ; \\
\mathrm{TTF}^{-}, \mathrm{CDX2}^{-}, \mathrm{PAX}-8^{-}, \\
\mathrm{CD}^{-} 0^{-}, \mathrm{S}^{-} 00^{-}\end{array}$ & G1 & $\begin{array}{l}\text { Asymptomatic at a } \\
9 \text { month follow-up } \\
\text { visit }\end{array}$ \\
\hline
\end{tabular}

${ }^{a}$ : Present case; $L V$ Left ventricle, $R V$ Right ventricle, RA Right atrium, $L A$ Left atrial, $F$ Female, $M$ Man, IHC Immunohistochemistry

was more frequent in patients with well-differentiated (grade I-II) tumors than advanced disease [4].

A high index of suspicion for metastatic disease in cardiac neuroendocrine tumor should prompt further investigations for identifying occult primary tumors. The most common primary sites of these tumors are the gastrointestinal tract, lungs, and mediastinum, followed by the skin (Merkel cell carcinoma) [16-19].

Certain imaging modalities such as CT and MRI might be used to assess the extended range of the tumor and diagnose primary tumors in the case of metastasis. We scanned the appendix, pancreas, lung, and gastrointestinal tract using CT but did not detect tumors of primary origin. At this stage, most pathologists may delegate the problem to the clinicians, leading to an ambiguous diagnosis.

Immunohistochemical markers are useful for identifying the origin of these tumors. Diagnostic pathologists routinely use $\mathrm{CDX} 2$ as a marker of intestinal-type adenocarcinomas. Two early immunohistochemical surveys reported that CDX2 expression is highly sensitive and fairly specific for neuroendocrine tumors of midgut origin (jejunoileum or appendix) [20, 21]. CDX2 shows high sensitivity and specificity for small intestinal NENs, whereas PAX8 is used to identify primary and metastatic pancreatic NETs [22]. TTF1 is most commonly used in diagnostic pathology as a marker of lung adenocarcinoma and thyroid tumors. In the setting of WDNET, TTF1 has been an incredibly specific marker for tumors of pulmonary origin, although the sensitivity varied [23-26]. A few groups have reported strong expression of PAX8 in the islets of Langerhans, which has been used to suggest the pancreatic origin of WDNET [2729]. CK20 is normally expressed by the gastric foveolar epithelium, intestinal epithelium, urothelial umbrella cells, and Merkel cells in the skin. Typically dot-like, but sometimes diffuse CK20 expression was observed in the vast majority of Merkel cell carcinomas [30, 31]. A review mentioned that the following marker panel is recommended for suspected WDNETs: broad spectrum keratins (CK), general neuroendocrine makers, CK20, TTF1, CDX2, and PAX8 [32]. Nevertheless, subsequently study have demonstrated expression of PAX-8 in NETs of extrapancreatic origin [33]. There are no immunohistochemical makers specific for NETs of the pancreas. It should be closely combined with imaging examination at this time. We performed immunohistochemical staining using this panel in the present case, and observed that the results were negative for all with the exception of the neuroendocrine markers and CK, because of which the site of origin could not be determined and the tumor was considered primary. However, effective immunohistochemical markers for determining the origin of these tumors were not available from the other cases reviewed. As no similar report has proposed the utility of immunohistochemistry in determining the origin of cardiac neuroendocrine tumors, information in this field is limited.

As primary cardiac NET is extremely rare, and randomized trials for NET patients with solitary cardiac involvement are lacking, individual choices have to be made. In general, tumor resection is the treatment of choice, which mostly leads to positive outcomes if macroscopically free tumor margins are ensured $[8,10]$. Treatment for high-grade neuroendocrine carcinoma usually consists of surgical resection and platinum-based 
chemotherapy [12]. Literature review indicated that alternative therapies (chemotherapy and radiation therapy) were considered when there was no possibility of resection; however, the prognosis was still poor $[6,7,9]$ due to remote metastasis. On the other hand, owing to the necessity of inducing immunosuppression, heart transplantation should be avoided in patients with systemic malignant tumor [6]. The tumor, which was histologically well-differentiated, was completely removed in the present case and the patient showed good outcome.

\section{Conclusions}

Cardiac NET is exceedingly rare and generally secondary to metastatic disease from a gastrointestinal source and other sites. The site of origin of a NET is clinically vital, and identification of occult primary tumors using imaging modalities and immunohistochemistry is necessary. Only when metastatic tumors are adequately excluded can primary cardiac NETs be diagnosed. Here, we describe the first case of primary cardiac NET presenting with diarrhea; we used imaging techniques and immunohistochemistry for determining the origin of the tumor. This type of rare tumor with unique clinical manifestation is possibly ignored by clinicians preoperatively, especially when the patient lacks typical cardiac symptoms. Furthermore, although surgical resection is the main treatment for well-differentiated cardiac NETs, early detection and correct diagnosis is undoubtedly the best option for patients. Regular follow-up is necessary for both poorly differentiated and well-differentiated cardiac NETs. It is worth noting that clinician should detect some neuroendocrinal markers for patients with unexplained reasons of diarrhea to find the cause. Finally, we expect that our case report will contribute to better recognition of these lesions and assist in avoiding inappropriate overtreatment.

\section{Abbreviations}

CDX2: Caudal type homeobox 2; CGA: Chromogranin; CK: Cytokeratin; CS: Carcinoid syndrome; CT: Computed tomography; IHC: Immunohistochemistry; MRI: Magnetic resonance imaging; NEN: Neuroendocrine neoplasms; NSE: Neuron-specific enolase; PAX8: Paired box gene 8; SYN: Synaptophysin; TTF-1: Thyroid transcription factor-1; WDNET: Well differentiation neuroendocrine tumor

\section{Acknowledgements}

We would like to thank Editage (www.editage.cn) for English language editing.

\section{Authors' contributions}

$\mathrm{CL}$ was a major contributor in writing the manuscript and concept of the manuscript. $\mathrm{XY}$ and $\mathrm{JH}$ evaluated the histopathological images and prepared the figures. JX performed the follow-up. GX provided pictures of imaging. HZ revised manuscript as well as guidance and editing throughout the writing process. All authors have read and approved the final manuscript.

\section{Availability of data and materials}

The data used and/or analyzed during the current study are available from the corresponding author on reasonable request.

Ethics approval and consent to participate

Not applicable

\section{Consent for publication}

Written informed consent was obtained from the patients for the publication of this case report and any accompanying images. A copy of the consent form is available for review by the Editor of this journal.

\section{Competing interests}

The authors declare that they have no competing interests.

\section{Author details}

'Department of Pathology, The Affiliated Hospital of Zunyi Medical University, Zunyi 563000, Guizhou, China. 'Department of Imaging, The Affiliated Hospital of Zunyi Medical University, Zunyi 563000, Guizhou, China.

Received: 26 November 2019 Accepted: 5 February 2020

Published online: 03 April 2020

\section{References}

1. Bakaeen FG, Reardon MJ, Coselli JS, Miller CC, Howell JF, Lawrie GM, Espada R, Ramchandani MK, Noon GP, Weilbaecher DG, et al. Surgical outcome in 85 patients with primary cardiac tumors. Am J Surg. 2003;186(6):641-7.

2. Hofland J, Zandee WT, de Herder WW. Role of biomarker tests for diagnosis of neuroendocrine tumours. Nat Rev Endocrinol. 2018;14(11):656-69.

3. Lichtenauer M, Pichler T, Eder S, Mirna M, Magnes T, Wernly B, Paar V, Jung $C$, Prinz E, Seitelberger $R$, et al. Carcinoid heart disease involving the left heart: a case report and biomarker analysis. ESC Heart Fail. 2019;6(1):222-7.

4. Halperin DM, Shen C, Dasari A, Xu Y, Chu Y, Zhou S, Shih Y-CT, Yao JC. Frequency of carcinoid syndrome at neuroendocrine tumour diagnosis: a population-based study. Lancet Oncol. 2017;18(4):525-34.

5. Perren A, Couvelard A, Scoazec J-Y, Costa F, Borbath I, Delle Fave G, Gorbounova V, Gross D, Grossma A, Jense RT, et al. ENETS consensus guidelines for the standards of Care in Neuroendocrine Tumors: pathology: diagnosis and prognostic stratification. Neuroendocrinology. 2017;105(3): 196-200.

6. Wißt T, Jehn C-F, Vierbuchen M, Starekova J. Solitary neuroendocrine carcinoma of the heart: a case report. Eur Heart J Case Rep. 2018;2(3):yty096.

7. Carmona P, Lázaro J, Llagunes J, Cánovas S. Primary cardiac neuroendocrine carcinoma and minimally invasive cardiac surgery. Asian Cardiovasc Thorac Ann. 2012;20(6):721-3.

8. Naqvi SY, Henry D, Furukawa S, Haber H. Primary neuroendocrine tumour of the right ventricle presenting with heart failure and cyanosis. BMJ Case Rep. 2016;2016:bcr2016-214810

9. Guajardo-Salinas GE, Anaya-Ayala JE, Rice DC, Moran CA, Reardon MJ. Primary high-grade neuroendocrine carcinoma of the heart. Tex Heart Inst J. 2013:40(1):71-4

10. Rogers MP, Thomas S, Nallamshetty L, Hooker R. Primary neuroendocrine tumour of the left ventricle. Eur J Cardio-Thoracic Surgery. 2020;57(4):806-8.

11. Öberg KE. Gastrointestinal neuroendocrine tumors. Ann Oncol. 2010; 21(Suppl 7):vii72-80.

12. Strosberg JR, Coppola D, Klimstra DS, Phan AT, Kulke MH, Wiseman GA, Kvols LK. North American neuroendocrine tumor S: the NANETS consensus guidelines for the diagnosis and management of poorly differentiated (high-grade) extrapulmonary neuroendocrine carcinomas. Pancreas. 2010; 39(6):799-800

13. Lips CJM, Lentjes EGWM, Höppener JWM. The spectrum of carcinoid tumours and carcinoid syndromes. Ann Clin Biochem. 2003;40(Pt 6):612-27.

14. Bertrand PP, Bertrand RL. Serotonin release and uptake in the gastrointestinal tract. Auton Neurosci. 2010;153(1-2):47-57.

15. Mawe GM, Hoffman JM. Serotonin signalling in the gut--functions, dysfunctions and therapeutic targets. Nat Rev Gastroenterol Hepatol. 2013; 10(8):473-86.

16. Jann H, Wertenbruch T, Pape U, Ozcelik C, Denecke T, Mehl S, Wiedenmann B, Pavel M. A matter of the heart: myocardial metastases in neuroendocrine tumors. Horm Metab Res. 2010;42(13):967-76. 
17. Pasieka JL, Schnell G, Abdel-Aty H, Rorstad O. Metastatic midgut carcinoid to the heart demonstrated on cardiac magnetic resonance imaging. Am J Clin Oncol. 2009;32(3):328-9.

18. Minicucci MF, Zornoff LAM, Okoshi MP, Bueno SP, Matsubara BB, Azevedo PS, Duarte DR, Paiva SAR, Marques M, Matsubara LS. Heart failure due to right ventricular metastatic neuroendocrine tumor. Int J Cardiol. 2008;126(2):e25-6.

19. Drake WM, Jenkins PJ, Phillips RR, Lowe DG, Grossman AB, Besser GM, Wass JA. Intracardiac metastases from neuroendocrine tumours. Clin Endocrinol. 1997:46(4):517-22.

20. Jaffee IM, Rahmani M, Singhal MG, Younes M. Expression of the intestinal transcription factor CDX2 in carcinoid tumors is a marker of midgut origin. Arch Pathol Lab Med. 2006;130(10):1522-6.

21. Lin X, Saad RS, Luckasevic TM, Silverman JF, Liu Y. Diagnostic value of CDX2 and TTF-1 expressions in separating metastatic neuroendocrine neoplasms of unknown origin. Appl Immunohistochem Mol Morphol. 2007: 15(4):407-14.

22. Yang MX, Coates RF, Ambaye A, Cortright V, Mitchell JM, Buskey AM, Zubarik R, Liu JG, Ades S, Barry MM. NKX2.2, PDX-1 and CDX-2 as potential biomarkers to differentiate well-differentiated neuroendocrine tumors. Biomark Res. 2018;6:15.

23. Kaufmann O, Dietel M. Expression of thyroid transcription factor-1 in pulmonary and extrapulmonary small cell carcinomas and other neuroendocrine carcinomas of various primary sites. Histopathology. 2000; 36(5):415-20.

24. Oliveira AM, Tazelaar HD, Myers JL, Erickson LA, Lloyd RV. Thyroid transcription factor-1 distinguishes metastatic pulmonary from welldifferentiated neuroendocrine tumors of other sites. Am J Surg Pathol. 2001; 25(6):815-9.

25. Agoff SN, Lamps LW, Philip AT, Amin MB, Schmidt RA, True LD, Folpe AL. Thyroid transcription factor-1 is expressed in extrapulmonary small cell carcinomas but not in other extrapulmonary neuroendocrine tumors. Mod Pathol. 2000;13(3):238-42.

26. Inafuku K, Yokose T, Ito H, Eriguchi D, Samejima J, Nagashima T, Nakayama H, Suzuki M, Yamada K, Masuda M. Two cases of lung neuroendocrine carcinoma with carcinoid morphology. Diagn Pathol. 2019;14(1):104.

27. Long KB, Srivastava A, Hirsch MS, Hornick JL. PAX8 expression in welldifferentiated pancreatic endocrine tumors: correlation with clinicopathologic features and comparison with gastrointestinal and pulmonary carcinoid tumors. Am J Surg Pathol. 2010;34(5):723-9.

28. Sangoi AR, Ohgami RS, Pai RK, Beck AH, McKenney JK, Pai RK. PAX8 expression reliably distinguishes pancreatic well-differentiated neuroendocrine tumors from ileal and pulmonary well-differentiated neuroendocrine tumors and pancreatic acinar cell carcinoma. Mod Pathol. 2011:24(3):412-24.

29. Haynes CM, Sangoi AR, Pai RK. PAX8 is expressed in pancreatic welldifferentiated neuroendocrine tumors and in extrapancreatic poorly differentiated neuroendocrine carcinomas in fine-needle aspiration biopsy specimens. Cancer Cytopathol. 2011;119(3):193-201.

30. Moll R, Löwe A, Laufer J, Franke WW. Cytokeratin 20 in human carcinomas. A new histodiagnostic marker detected by monoclonal antibodies. Am Pathol. 1992;140(2):427-47.

31. Tanaka Y, Sano T, Qian ZR, Hirokawa M. Expression of adhesion molecules and cytokeratin 20 in merkel cell carcinomas. Endocr Pathol. 2004;15(2):117-29.

32. Bellizzi AM. Assigning site of origin in metastatic neuroendocrine neoplasms: a clinically significant application of diagnostic immunohistochemistry. Adv Anat Pathol. 2013;20(5):285-314.

33. Koo J, Zhou X, Moschiano E, De Peralta-Venturina M, Mertens RB, Dhall D. The immunohistochemical expression of islet 1 and PAX8 by rectal neuroendocrine tumors should be taken into account in the differential diagnosis of metastatic neuroendocrine tumors of unknown primary origin. Endocr Pathol. 2013:24(4):184-90.

\section{Publisher's Note}

Springer Nature remains neutral with regard to jurisdictional claims in published maps and institutional affiliations.

\section{Ready to submit your research? Choose BMC and benefit from:}

- fast, convenient online submission

- thorough peer review by experienced researchers in your field

- rapid publication on acceptance

- support for research data, including large and complex data types

- gold Open Access which fosters wider collaboration and increased citations

- maximum visibility for your research: over $100 \mathrm{M}$ website views per year

At BMC, research is always in progress.

Learn more biomedcentral.com/submissions 